\title{
The development of a social-cognitive model for a better understanding of the female adolescent suffering from anorexia nervosa
}

\author{
Esther van der Spuy, Helena M de Klerk and Rozanne Kruger
}

\begin{abstract}
OPSOMMING
Eetversteurings word beskryf as eetgedrag wat die individu se fisieke of psigiese gesondheid benadeel. Eetversteurings soos anoreksia nervosa is vandag algemeen onder adolessente en word algemeen gereken as ' $n$ komplekse verskynsel wat deur ' $n$ verskeidenheid van bydraende faktore beïnvloed word.
\end{abstract}

Die doel van die outeurs was om 'n navorsingsmodel te ontwikkel wat op die sosiaal-kognitiewe belewenisse van die vroulike adolessent met anoreksia nervosa fokus en wat veral deur voedingkundiges (en verwante dissiplines) gebruik kan word in die bestudering van hierdie groep. Die simboliese interaksionisme en 'n sosiaal-kognitiewe perspektief is as vertrekpunt geneem. Dit plaas die klem op veral die individu as aktief-denkende wese wat voortdurend in interaksie met haarself en ander, kognitiewe prosesse in werking stel om bepaalde persepsies van haarself, ander en die situasie te kan vorm. Met so 'n uitgangspunt is dit moontlik om vanuit die literatuur oor die adolessent met anoreksia nervosa op belangrike aspekte te fokus soos haar belewenis van die verskillende aspekte van haar self asook haar belewenis van betekenisvolle, veralgemene en verwysingsgroep ander. Die outeurs is van mening dat so ' $n$ model die voedingnavorser in staat stel om die adolessent met anoreksia nervosa in totaliteit te bestudeer ten einde haar gedrag te kan verstaan en ryklik te beskryf.

\section{- Mrs HH van der Spuy}

- Prof HM de Klerk

- Dr R Kruger

Department of Consumer Science,

University of Pretoria

\section{INTRODUCTION}

Eating disorders are described as disorders in eating behaviour that harms a person's physical and psychological health (Whitney \& Rolfes, 1999:282). According to many authors and researchers, including Fabian and Thompson (1989), Neumark-Sztainer and Storey (1998), Mclntosh (1999:6), Kowalski (2000) and Field et al (2001), eating disorders are a significant problem among adolescents. Adolescence is the developmental stage between childhood and adulthood and starts between the years 10 and 13 and ceases between 17 and 21 years (Thom et al, 1998:388). The female adolescent develops a greater percentage body fat during this stage and her body shape changes, which immediately induces problems of self-image and phobias about weight loss (Wardlaw, 1999:604; Kowalski, 2000; Whitney et al, 2001:276). Anorexia nervosa is one of the eating disorders occurring in adolescence. Fieldhouse (1995:188) contends that obesity and anorexia nervosa are conditions that originate as a result of, or can lead to abnormal food consumption patterns that are totally separated from the actual physiological needs. Anorexia nervosa is defined in Dorland's Pocket Medical Dictionary (1982) as "a psychophysiologic condition, usually seen in girls and young women, characterized by severe and prolonged inability or refusal to eat, sometimes accompanied by spontaneous or induced vomiting, extreme emaciation, amenorrhoea (impotence in males), and other biological changes. According to authors Whitney et al (2001:160) and Barlow and Durand (1999:234) anorexia nervosa is characterised by extreme selfstarvation, refusal to keep to a minimal body mass and a distorted perception of body mass and body form in conjunction with anxiety disorders and mood swings. These are conditions that generally occur in all phases of adolescence. The most predictable factor for anorexial behaviour, according to authors Moore (1993) and Thom et al (1998:388), is a poor self-image and associated depression.

In accordance with the American Psychiatric Association (DSM 1V), as cited by by "Nutrition intervention in the treatment of anorexia nervosa, and eating disorders not otherwise specified" (2001), the following diagnostic criteria are used to diagnose patients with anorexia nervosa:

- a body mass of less than $85 \%$ of what it ought to be

- an intense fear of any increase in mass, even though underweight 
- a distorted way in which the individual evaluates body mass, with a perception of being overweight even when thin

- absence of at least three consecutive menstrual cycles

Accurate South African statistics on the prevalence of anorexia nervosa are not available. Determining accurate statistics is difficult because physicians are nor required to report eating disorders to a health agency, and because people with these problems tend to be secretive, denying that they even have a disorder, there is no way of knowing exactly how many people in this country are effected. It is far more common among women than men $(90 \%$ of sufferers are women) and usually strikes during early adolescence and young adulthood (Health 24: Woman common conditions, accessed 2003). According to the position statement of the American Dietetic association (1998) more than 5 million Americans suffer from eating disorders. Five percent of females and $1 \%$ of males have anorexia nervosa, bulimia nervosa, or binge eating disorder.

Despite the importance of healthy eating patterns during adolescence, the pressures on adolescents to comply with social norms are so great that the adolescent do not always adhere to the physiologic requirements of this development stage. As a result of their need to conform to the peer group, it is very important to appear slender. As a result of a don't-care attitude about future health, it follows that a healthy eating regimen has a low priority with female adolescents (Neumark-Sztainer et al, 1999). More than $90 \%$ of the anorexia nervosa cases occur in young women from families with a high socio-economic status and residing in a socially competitive community (Barlow \& Durand, 1999:237-239). According to Barlow and Durand (1999:237) biological, psychological, and social factors can contribute to the development of serious eating disorders such as anorexia nervosa, but the most recognised factors appear to be social and cultural in nature.

The phenomenon of adolescent anorexia nervosa therefore presents a complex character with a variety of contributing factors. Little nutrional research has so far been done from a social-cognitive perspective focusing on the inner perceptions of the adolescent with anorexia nervosa (Fabian \& Thompson, 1989; Field et al, 2001). With an approach that focuses on the social-cognitive perceptions of the female adolescent with anorexia nervosa, a useful contribution can be made in a better understanding of this eating disorder (Fabian \& Thompson, 1989). The aim of this article is therefore to develop a research model that focuses on the social-cognitive perceptions of the female adolescent with anorexia nervosa which can be used by nutrionists in a better understanding of this group. The symbolic interactionism and a social-cognitive perspective are used as points of departure. For the purpose of this article the feminine pronoun will be used and "the anorexic adolescent" refers to the female adolescent with anorexia nervosa.

\section{THE DEVELOPMENT OF A SOCIAL-COGNITIVE CONCEPTUAL MODEL}

\section{Symbolic interactionism}

Blowers et al (2003) underline the fact that theoretical models such as the symbolic interactionism, investigating the specific mechanism by which various factors influence disordered eating behaviour, have only recently appeared in literature. Symbolic interactionism focuses specifically on social interaction and on the dynamic, social activities that occur during interactive situations between people and in the individual himself (Charon, 1998:27-28). Symbolic interactionism, with underlying assumptions and specific concepts, highlights not only what occurs in interaction between individuals, but also within the individual self. The theory of symbolic interactionism is a micro-level theory that focuses on subjective interpersonal significances and the ways in which interaction occurs between people through verbal and nonverbal symbols. The following assumptions and concepts are relevant for this study:

- Human actions are not only determined by social interaction, but also by interacting with the self which may be seen as an object consisting of the physical self (the body), the material self (clothing, possessions, food, etc), the spiritual self (which includes aspects such as personality traits, values, attitudes, etc) and the social self (the individual as part of the group, community, etc). The self as object may also be rated and evaluated. "The self is something we judge, evaluate, like, reject, love or hate. We may feel good as we look at ourselves; we may feel bad" (Charon, 1998:82-83). The self as object may thus attain meaning for the individual and serve as symbol, which she then can communicate to herself and others. In the case of the anorexic adolescent it would mean that she experiences herself in interaction with her self and also with others and that aspects of her physical, material, social and spiritual self, for example her body or her refusal to eat obtains meaning for her and she then can communicate this as symbol to herself and to others.

- The self develops during interaction with others who not only give feedback to the individual regarding the self, but with whom the individual also compares herself (Cooley in Kaiser, 1990:165). These other individuals include significant others (family and loved ones), reference group others (for example the peer group) and generalised others (people in general, culture group, stereotypes, etc). For the female anorexic adolescent the others with whom she compares herself and from whom she receives feedback could play a significant role in her development and perception of herself, which may direct her subsequent behaviour in a specific direction. Blowers et al (2003) maintain that pressure from significant others, reference group others and generalized others, such as the family, peers and media, may lead to individuals' 
internalising societal messages about the importance of thinness and that this, in turn may lead to a schematic set of beliefs about the importance of thinness and beauty for success in a woman's life. In addition Heilman (1998) found that there were already in 199810 times as many advertisements promoting the thin figure and dieting in magazines read by young females compared to those read by young males and that even products with no apparent connection to body size were advertised by appealing to girls' concern with weight. Young women are therefore important targets for advertisers and thus for weakened self-images and specifically body images. According to Marcotte et al (2002) girls therefore become more depressed than boys during their teenage years. In addition to this Furnham et al (2002) found that male selfesteem was less affected by body-dissatisfaction than that of females.

- Social interaction with others and with the self and a definition of the situation is therefore central to the perspective. The anorexia nervosa sufferer's constant interaction with herself fills an important part in her perception and evaluation of herself. In addition interaction with others and with the self implies that the individual is actively involved in situations and is responsible for her own behaviour. Charon (1998:75) indicates that without a self, the individual would not be able to communicate with others. Mead as cited by Kaiser (1990:149) makes it clear that "What is essential to communication, is that the symbol should arouse in one's self what it arouses in the other individual". When the individual is in communication with herself, she analyses and defines the specific situation wherein she finds herself. Information about others, the situation and her self are effectively shown and allows her to understand her specific position in the situation. Thus she obtains a perspective of herself and is able to apply selfcontrol and direct her behaviour in a specific direction. Significant self-control is a characteristic of the anorexia nervosa sufferer and she displays a strong willpower and makes unyielding decisions about her eating habits (Slabber, 1985).

\section{Social-cognitive perspective}

In connection with the symbolic interactionism the social-cognitive approach places special emphasis on the cognitive processes that people use during the interaction with the self and with others in order to form specific perceptions, to understand their own behaviour and the behaviour of others, to make sense of the situation, and, eventually, to direct their own behaviour accordingly (Baron \& Byrne, 1987:76). The following assumptions and concepts are relevant for this research:

- Objects such as clothes, food and personal appearance are often used to simplify social interaction and to gain sense from the interaction. These objects usually serve as symbols and may be significant with regard to the self and others and con- tribute to the process of forming perceptions (Kaiser, 1990:165).

- Humans tend to strive to some uniformity and continuity in their perceptions and they use various cognitive shortcuts and strategies such as selfschemata and stereotyping in order to form perceptions quickly and accurately. Thought shortcuts and strategies that an individual makes over time enables her to cope with the circumstances in which he finds himself and to make sense in an effective way about the complex social world in which he finds himself and to direct his own behaviour accordingly (Baron \& Byrne, 1987:77).

- Schemata are cognitive structures or models that enable a person to organise a large amount of diverse information about himself, others and events in an effective manner (Fiske \& Taylor cited by Baron \& Byrne, 1987:77). These cognitive models contain information relevant to the specific situation, occurrence or person, for example a self-schemata that, according to Baron and Byrne (1987:77) is the individual's own organised image of all the aspects of his self. This enables the individual to organise information about himself, to interpret the specific situation in which he is involved, and to direct his behaviour accordingly. Research by Fairburn and Garner (cited in Eldredge et al, 1990) underline the importance of cognitive and affective structures in eating disorders. A suitable approach for studying the body image is, according to Jung et al (2001), the scheme theory that forms part of the cognitive perspective. Scheme theory focuses therefore on cognitive processes that are related to personality, the influence and cognitive organisation on selfperception, and behaviour (Bern, cited in Eldredge et al, 1990). A self-schemata could therefore be seen as a cognitive generalisation of the self that is derived from previous experiences and learning. The sufferer from anorexia nervosa with a negative self-image will therefore process received information selectively and could have negative feelings about herself. For the anorexic assumptions, attitudes, and convictions about the significance of body mass, are central to self-evaluation (Eldredge et al, 1990). This could be because her body image is imagined or wholly consists of her exclusive perception of her body size, or according to Blowers et al (2003) because of the internalisation of the thin ideal whereby certain women come to accept and maintain a rigid belief that being thin is necessary to be attractive. Internalisation of the thin ideal has consistently been found to predict levels of body-dissatisfaction and eating disturbance (Blowers et al, 2003). In addition to this Vander Wal and Thelen (2000) found that, already during the elementary age school years, bodymass plays a major role in girls' body-image and that body-mass is one of the most important factors that influences body satisfaction and dissatisfaction.

- Categorising is the first cognitive step that leads 
to stereotyping. A stereotype would, according to Baron and Byrne (1987:101-103), be seen as fixed organised and inflexible schemata of specific roles and events. The use of stereotypes as cognitive shortcuts may result in the person selectively using and encoding information about events or situations and instead of going through the process of perception forming, rather using a shortcut or the oversimplified and usually rigorist schemata (stereotype) as a shortcut in creating a specific picture of himself, others and events. Stereotyping of behaviour and popularity is associated with body types (Burns, 1981:151-156). According to researchers such as Blowers et al (2003) just about every Western adolescent regards a slender figure as the ideal. These researchers found that body-mass of pre-adolescent girls have a direct association with body-dissatisfaction. Furthermore Blaine and McElroy (2002) found that the stereotyped thin woman appeared three times as frequently as heavy weight women in television programmes and that heavy weight women were portrayed as unhappy, unattractive and lacking in willpower. For the adolescent with anorexia nervosa this stereotypical viewpoint is probably the only view that makes sense to her and she will often go to extremes in an attempt to reach that ideal. Stereotyping is often reinforced with remarks such as "slim is beautiful" and "slim is wonderful" and such factors put tremendous pressure on adolescents. If they feel that they cannot comply with the indicated standards, their self-images suffer and in some instances this can lead to eating disorders (Kowalski, 2000). Stereotyping can become dangerous when the adolescent does not quite measure up to the category, but she is still part of the group. In the same measure that she has a wrong perception about her body, she will have a misconception about food. In addition to this Puhl and Brownell (2003) underline the fact that, although there is not yet sufficient research to determine the exact prevalence of weight stigma, there is evidence of clear and consistent weight prejudice in major life areas of employment, health care and education. Weight is often linked to certain personality traits and personality traits such as successfulness and perseverance are attributed to thin women.

- A human being is motivated to explain social events and results in terms of humans and situations. A human being has a basic inborn need to know why things happen and why others as well as the individual himself behave as they do. This so-called process of attribution and self-attribution is not only internal in nature, but external information is used to weigh and to evaluate. The adolescent with anorexia nervosa is also interacting with her own self. Self-communication helps her to see and understand herself. She is conversing internally with herself about her self and she talks to herself about how she should act in specific situations, or what the reasons are for her behaviour, for example why she does not eat (Charon,
1998:81). Attribution and self-attribution are concerned with the causes (whether internal or external to the individual) that contribute to specific behaviour; these thus provide the knowledge to understand why people, as well as the individual himself, act in specific ways under certain circumstances. The adolescent evaluates and compares her own behaviour about eating and weight management, and tries to understand her feelings, attitudes and behaviour. In a certain sense she is conversing with herself. She, quite possibly, makes use of symbols such as food and clothes to evaluate her physical, spiritual, social, and material self and to form a perception of herself. Blowers et al (2003) propose that the relationship between internalisation of the thin ideal and body dissatisfaction is further influenced by the effects of individual social comparison processes. Social comparison refers to the process of thinking about information of other people in relation with the self, either passively (by acquiring social information somewhat sub-consciously) or actively (engaging in goal directed behaviour such as selecting a comparison "target" that is suitable for one's aims). Amongst adolescent girls who actively choose inappropriate targets (for example very thin models), this may lead to eating disorders.

From the above short discussion about the use of the symbolic interactionism and a social-cognitive perspective as departure point in the study of the adolescent with anorexia nervosa, the following schematic model is provided.

\section{INTERPRETATION OF THE CONCEPTUAL MODEL WITH REFERENCE TO THE ANOREXIC ADOLES- CENT}

The adolescent with anorexia nervosa in interaction with her self

From the conceptual model it is apparent that the female adolescent with anorexia nervosa is constantly interacting with herself during which time she experiences the various aspects of the self. And from a social-cognitive perspective it could further be argued that during this interaction with the self she initiates cognitive processes, such as using aspects of the self as symbol of specific other aspects of the self, and in this manner making use of a self-schemata or stereotypes as shortcuts, or in the process of self-attribution trying to find reasons and causes for her own behaviour. This interaction with the self and the use of specific cognitive processes and strategies enables her to develop a perception of the self, to change the self and also to direct her behaviour accordingly. These make it also possible for her to evaluate the various aspects of the self and to perceive such as either positive or negative.

Perceiving the physical self From the literature it is apparent that adolescents are aware and concerned about their physical appearance 


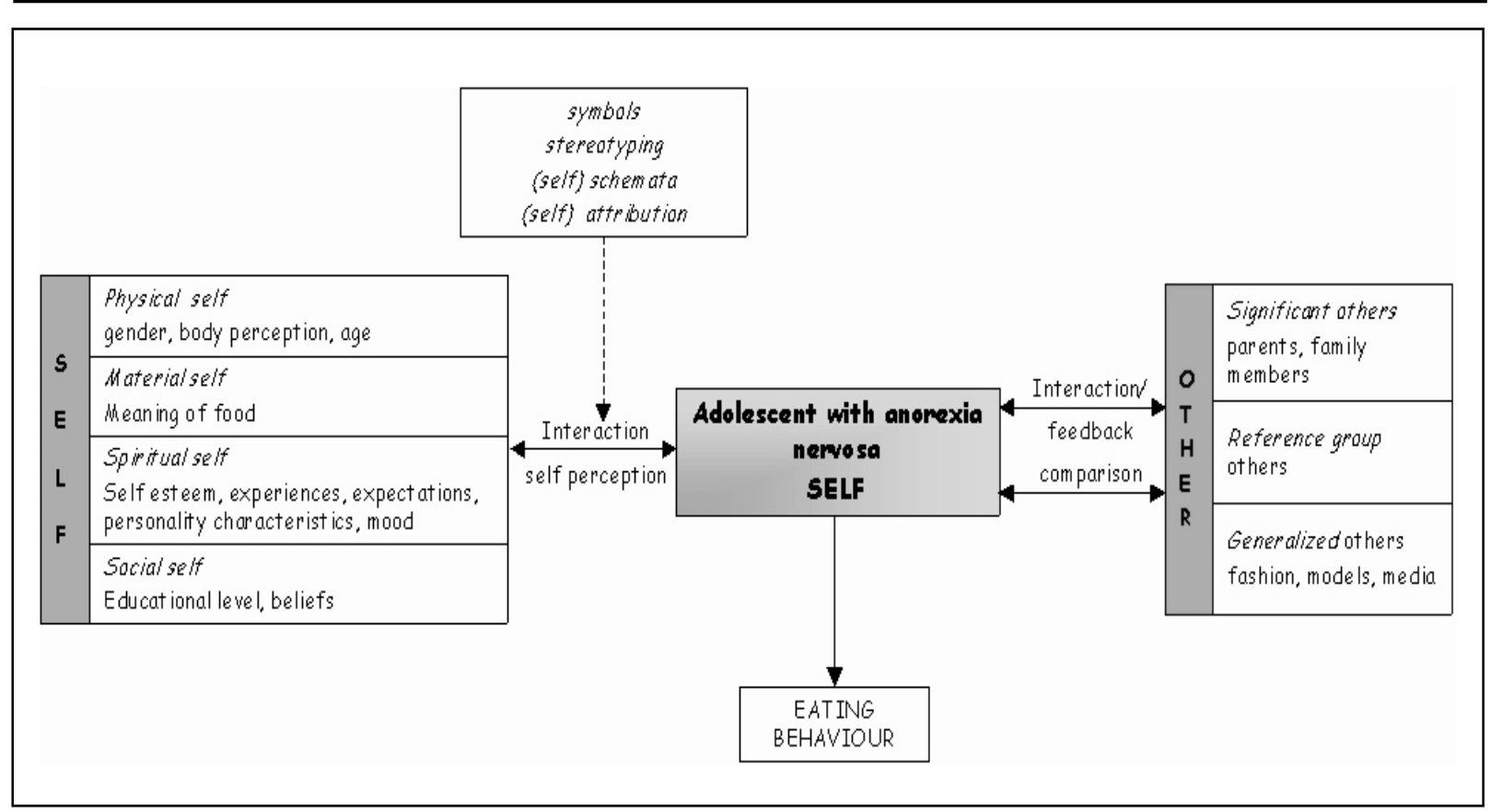

FIGURE 1: INTEGRATED CONCEPTUAL FRAMEWORK FOR STUDYING THE FEMALE ADOLESCENT WITH ANOREXIA NERVOSA

(Neumark-Sztainer et al, 1999; Nicht, 2000; Blowers et al, 2003). The positive points as well as the shortcomings (those actually existing and those imagined) in their physical appearance play an important role in the development and experiencing of the self (Burns, $1981: 6,151)$. The same author contends that body image is a very important concept in perceiving the self. "Body image refers to the mental picture one has of his or her body at any given moment in time" (Kaiser, 1990:98). A positive body image correlates strongly with an acceptance of the physical body. The body image of the female adolescent with anorexia nervosa is therefore in essence the perception of her physical self. The ideal body image is based on acquired cultural norms and stereotypes. "The closer the match between the existing body image and the ideal held by the individual, then the more likely will that person manifest high self esteem generally as well as feel positive about his appearance" (Burns, 1981:156). Researchers such as Vander Wal and Thelen (2000) maintain that dissatisfaction with body image already correlates positively with the eating behaviours of elementary-age schoolgirls. In addition to that Muir et al (1999) found that body-dissatisfaction plays a major role in adolescent girls' self concept and was also given as a major reason for their first diets. Adolescents who have anorexia nervosa or tend to suffer from eating disorders, often have a distorted body image accompanied by a very low self-esteem, and sometimes even depression. They picture themselves as larger than their ideal body image (Touyz et al, 1984; Fabian \& Thompson, 1989; Tiggemann, 1992; Moore, 1993; Hill \& Bhatti, 1995; Thompson \& Chad, 2000), and strive to be thinner than at present (Kruckenberg, 1987:55; Drewnowski et al, 1995). This misconception is reinforced by the mass media and the fashion industry that persist in using skinny models to fashion clothes, which is only suitable for emaciated figures (Kaiser, 1990:104; Barlow \& Durand, 1999:237). According to Kilbourne (cited in Benokraitis, 1999:417) women are conditioned to fear fat: "Prejudice against fat people, especially against fat women, is one of the few remaining prejudices that are socially acceptable". Benokraitis (1999:417) points out that women attempt to live according to the Western stereotype that beauty and slenderness are necessarily the same. For Benokraitis this is the main cause of anorexia nervosa and bulimia. He puts it as follows: "Anorexics and bulimics become obsessed with living up to an image of beauty promoted by the media and fashion industry" (Benokraitis, 1999:417). In addition young adolescents often abstain from food to preserve a wraithlike (anorexic) appearance.

From the above overview of the literature about the anorexic adolescent's perception of her physical self, it would appear that she is interacting with herself, that she forms a distorted perception of her physical self, and that cultural standards and stereotypes, which are used as shortcuts in cognitive schemata in judging the physical self, may also play a role. Because the perception of her physical self is probably primarily linked to her body weight and size, this could also lead to disordered eating behaviour.

Perceiving the material self Kaiser (1990:95) accepts the view of James about the material self as the physical aspects that pertains to the self in the form of possessions such as clothes and food and thus becomes part of the self and may also be used to manipulate the physical self and in a certain manner be projected to the person self and to others. The adolescent with anorexia nervosa probably uses food and clothes as symbols to give meaning to her behav- 
iour. A person is able to create symbols, to manipulate them and to use them in communicating and interacting with himself and others. Symbols always imply meaning - in this case probably meaning concerning the self. The anorexic adolescent sometimes uses clothes to hide her emaciated body (Slabber, 1985; Kaiser, 1990:104). Included here is Fisher and Cleveland's view (in Kaiser, 1990:106) that an overemphasis of certain aspects of the physical self, such as body size and weight could lead to a distorted perception of the limits or boundaries of the body. The adolescent suffering from anorexia nervosa has probably also got a distorted perception of the boundaries of her body as these are distinguished from surrounding space. Fisher and Cleveland (as cited in Kaiser, 1990:106) point out that dissatisfaction with the body boundaries could lead to the need to manipulate the physical self and to present it differently to others during social interaction. The adolescent with anorexia nervosa may use aspects of the material self such as food and clothes for this purpose. "The whole concept of body image boundaries has implicit in it the idea of the structuring of one's relations with others. It would seem to follow that if the body image concept has something to do with the kind of defensive barriers an individual establishes ... an understanding of these barriers should tell us something about the nature of the person's interactions with others" (Fisher \& Cleveland, in Kaiser, 1990:106). Such an approach points to the interaction between the various parts of the self and therefore supports the view of symbolic interactionism that the individual, in this instance the adolescent with anorexia nervosa and her behaviour, has to be studied as a whole and in its interaction with others and that individual reasons and causes for specific behaviour should not be isolated.

In addition the female adolescent with anorexia nervosa has a distorted view of the role of food in her life. She has an obsessive preoccupation with food, but at the same time she does not allow herself to enjoy it (Kaiser, 1990:104; Kowalski, 2000). Food is a burgeoning menace for her because she associates it with weight increase. Her obsessive fear of becoming overweight forces her to the point to manage without any food, thus literally starving herself to death (Barlow \& Durand, 1999:240; Kowalski, 2000). She exhilarates in her relationship with food and regards eating as an inner experience that she does not want to share with others (Slabber, 1985). Her manipulation of her material self (appearance and food behaviour) can serve as symbol for her of specific aspects of, for example, her spiritual self, for example that she infers that she has a strong willpower (Wardlaw, 1999:352).

From the foregoing the nuanced interplay between the physical and material aspects of the self and the individual's interaction with others is clear, as well as the fact that aspects of the material self such as food and clothing probably can be used by the anorexic adolescent, not only in the manipulation and presentation of the body (physical self), but also as symbol and significance relating to other aspects of the self.

Experiencing the spiritual self The spiritual self is concerned with thoughts and feelings relating to the inner person, for example values, capabilities, attitudes, and personality traits (Burns, 1981:7; Kaiser, 1990:289). All the other forms of the self centres around the spiritual self. It is the source of interest, attempts, attention, will, and choice, and, furthermore, it is a summary of the intellectual, religious, and moral aspirations of the individual (Burns, 1981:7). From the symbolic interactionism it is apparent that the spiritual self is an important part of the self and that it has a definite role in behaviour (De Klerk, 1995). "Values are self-organising principles that guide our thoughts and actions. These values are linked to self-concept and self-evaluation - values are abstract" (Kaiser, 1990:289). In addition, values as part of the spiritual self assist the individual to define those aspects that are important for her and direct her choices and predilections (Kaiser, 1990:289). Depending on the anorexic adolescent's values, she will make important decisions about her eating behaviour. The spiritual self of the anorexic may probably be better understood by looking at the profile of a typical anorexia nervosa sufferer:

- she is usually young, intelligent and performance oriented and superior

- performance for her is to have a noticeably slender figure (Barlow \& Durand,

- 1999:237; Kaiser, 1990:104; Tiggemann \& Dyer, 1995),

- she displays a visible strong willpower and is competitive by nature and at times obsessive,

- in most cases much is expected from her and the eating disorders probably make it possible for her to exercise control in an otherwise futile existence

- losing weight was probably her first success that she had achieved independently (Wardlaw, 1999:604)

- she is a perfectionist and she evaluates her spiritual self-worth in terms of self-control (Barlow \& Durand, 1999:237; Wardlaw, 1999:352; Gardner, cited in Tiggemann \& Dyer, 1995)

- by manipulating the size of her body she experiences control over her life (Kaiser, 1990:104), and

- the adolescent with anorexia nervosa often experiences a feeling of failure in human relationships, isolates herself socially and substitutes the world of social relationships with a world of food, eating and considerations of weight (Kaiser, 1990:104; Wardlaw, 1999:352).

The emphasis that symbolic interactionism places on the interplay between the various aspects of the self, is once again apparent, as well as the fact that one aspect of the self may serve as symbol for other aspects of the self. The use of cognitive processes such as self-attribution and the use of symbols to provide meaning to situations of social interaction are also clear.

Experiencing the social self The social self can be defined as the self being part of others or as 
part of a group or community. From the symbolic interactionism it is apparent that the complete self is a social object that develops when interacting with others, for example the significant others, generalised others and the reference group others (Charon, 1998:7). Charon (1998:81-82) explains that the individual, in this case the anorexic adolescent, is capable of visualising herself in the position of others, to accede to their roles, and to judge her own self from the perspective gained from perceiving others, or what she considers their perspectives to be. Others therefore play important parts in the development of the total self of the anorexic adolescent.

Below attention is given to the development of the self of the female anorexic adolescent as she interacts with others.

\section{The adolescent suffering from anorexia nervosa in interaction with others}

With the symbolic interactionism as background it is clear from the conceptual model that the anorexic adolescent is also constantly interacting with other people and that her self develops while interacting with others. These others with whom she continually compares aspects of her self and from whom she obtains feedback about her self, includes significant others (parents and family), generalised others (fashions, stereotypes and the views of the mass media) and reference group others (peer group and other groups with whom she identifies). From a social-cognitive perspective it can be added that she not only receives feedback from the others, and that she compares herself with others and adopts their roles, but that during interacting with others she activates cognitive processes in order to understand the interacting situation, her own behaviour and that of others, and from that eventually forms a perception of her whole self.

\section{Interacting with significant others}

From the literature it would appear as if the interaction of the anorexic adolescent with significant others such as parents, brothers and sisters, plays a determining role in her perception of her self and on her eventual eating behaviour. Theoreticians and researchers such as Gormly and Brodzinsky (1989:307-315) point out that the cognitive and social development during adolescence often lead to conflict in the family and disordered parent-child relationships could be problematic for the adolescent. It is usually during this phase of life when the adolescent has a need for more autonomy and starts to rebel against rigid rules, regulations and external pressures, whether from the family, school or further a field (Gormly \& Brodzinsky, 1989:328-330; Pretorius, 1988:139). Research about the role of the family and specifically that of the father and the mother as significant others indicates that factors such as weak parent-child relationships, parenting styles, specific pressures from parents and others could have a determining effect on the adolescent's perceptions about her self, as well as her eating behaviour and should therefore not be disregarded in attempting to reach a better understanding of the anorexic adolescent (Hart \& Kenny, 199; Blades, 2001).

Hill and Bhatti (1995) found for example that the family environment could contribute to the pathogenesis of eating disorders such as anorexia nervosa. Byely et al (2000) determined that girls in early adolescence, with a negative perception of family relationships, are more prone to have disordered eating behaviours. Pressure is often put on daughters to be thin (Pike \& Rodin, cited in Byely et al, 2000). Field et al (2001) found that the influence of parents could lead to an anxiety and obsession about weight and be associated with slimming diets on a regular basis. Male family members such as the father appear to have an important effect on the decision of the female adolescent to start with a slimming diet (Moore, 1993; Field et al, 2001). The feedback relating to her perception of her body that the adolescent gets from her family members could lead to abnormal eating behaviour.

Some individuals could develop eating disorders in an attempt to cope with the parents' unreasonable expectations. The endeavours of adolescents to function independently are curbed by the strict and rigid control from their parents. Various theoreticans also point out that anorexic adolescents often come from homes where the parents are strict and rigid and often have an authoritarian style of parenting. A dominant mother with a preoccupation about weight and diets and an emotional and physical absent father are regularly referred to (Norris, 1986). The anorexic adolescent usually tends to be exemplary in all respects and respects her parents' wishes at all costs, which leads to enormous internal conflict and even depression. Refusal to eat is often the only form of control that an adolescent has in her life and control is essential for her.

In addition to the foregoing Dalzell (2000) adopted a feminist-informed model in studying the role of the family in eating disorders amongst adolescents. The researcher holds that anorexic females have rigid role prescriptions and value loyalty and family tradition above all. Family conflict is also usually prohibited.

From the foregoing it would appear that social feedback in, for example, the form of criticism or expectations of aspects of the self, especially from the parents as significant others, probably plays an important role in the development of the female adolescent with anorexia nervosa and her perception of her self and possibly eventually on her eating behaviour as well.

Interaction with reference group others From the symbolic interactionism it is clear that reference group others play a necessary part in the development of the self because the individual compares herself with this group and often gets feedback from them about her self. Kaiser (1990:129-130) points out that adolescents are more likely to compare their visible, physical selves with reference group others, especially the peer group, and that they also regard the feedback 
from this group as important. Theorists such as Gormly and Brodinsky (1989:331-336) and Thom et al (1998:458) agree that the peer group as reference group others has an important influence on the adolescent's perception of her self and her behaviour during the adolescent phase. Field et al (2001:56) postulate "To gain acceptance by their peers, adolescents may resort to adopting the perceived beliefs and behaviours practised by the members of their peer group". This causes the adolescent to become increasingly introspective and analytical, especially when she does not comply with the standards of the peer group. This could result in mood swings that varies from depression and dissatisfaction to joy and happiness (Thom et al, 1998:429). Peer pressure was found to be a risk factor in eating disorders (Field et al, 2001). Feedback from the peer group in the form of teasing about being overweight, especially in early adolescence, could sometimes result in eating disorders and this aspect should never be underestimated. This exceptionally damaging form of feedback could have a negative effect that could continue into adulthood (Burns, 1981:153; Fabian \& Thompson, 1989; Taylor et al, 1998).

A characteristic of adolescent peer group relationships is the increase in conformity. Conformity refers to the tendency to give in to social pressure. Excessive conformity with the peer group could lead to adolescents getting involved with high-risk behaviour situations (Thom et al, 1998:458). If the adolescent compares herself with her peer group about her weight and figure, and she does not comply with the standards, she might pursue extreme practices in an attempt to conform. Young adolescents are more prone to conform than late adolescents because they are very sensitive to the approval of the peer group and because of a lack of confidence and independence to make their own decisions. It therefore appears that the dependence on a peer group is a required step in the development of adolescents towards becoming independent from their parents (Thom et al, 1998:457). As has already been indicated adolescents with eating disorders sometimes are under strict supervision of their parents and the adolescents avoid social contact for various reasons. This impedes the normal development of independence and could lead to other emotional problems. The appearance of the adolescent is often more important for her than her health and her self-esteem; happiness and success is often determined by her body measurements and percentage body fat (Barlow \& Durand, 1999:237). Unpopular adolescents are often emotionally unsettled, obsessed with themselves, and display a negative self-image (Thom et al, 1998:457). This creates a good climate for the development of eating disorders, especially if it is accompanied by other causative factors. Her peer group's "positive" feedback can reinforce her problem. Remarks such as "You look so marvellous, I wish I looked like you!" and "I wish my willpower was as strong as yours" will serve as motivation for her to persevere with her damaging behaviour and the remarks are regarded as a social reward (Kaiser, 1990:105; Lieberman et al, 2001).
Adolescents are inclined to establish close friendships with those displaying similar characteristics. They tend to select friends whose interests, attitudes, values, and personalities agree with theirs (Brendt \& Perry, cited in Thom et al, 1998:460). They have a need for self-revelation and would rather discuss their physical changes and awakening sexuality with their friends than with their parents (Thom et al, 1998:460). Self-revelation between close friends assists adolescents in learning to know themselves better and to be sensitive about others. The adolescent with anorexia nervosa often has to forgo these friendship relations and is dependent on herself to cope with emotional problems. Reasons for this may be her unwillingness to socialize with peers due to the fact that she fears their remarks on her unacceptable thin body, or to the fact that she fears any situation where peers will expect of her to join them in eating or drinking. Another reason may be that she feels stigmatised and therefore withdraw from social situations. According to Goffmann (1963:3-4) a stigma refers to any physical, psychological or social attribute that dissociate the person from other so-called normal people. This may include the physically handicapped and also the person with anorexia nervosa whose physical appearance differs from those of most other people. Goffmann (1963:6-19) is of the opinion that the stigmatised person, in many cases, withdraw from social contact. This then may be an attempt not to be confronted by the differences between the person and other so-called normal people. Furthermore, she is self-directed and she is only interested in herself and her eating practices. Friendships help to alleviate the stressors of adolescence, combat loneliness, and contribute to the development of a self-concept. The social isolation and loneliness is a negative experience that can hamper the development of the social self and negatively affect experiencing the spiritual self. A lack of contact with the peer group obstructs normal social development of the anorexic adolescent and fosters her pre-occupation with food (Reiff \& Reiff, 1992;126). Persons with eating disorders often withdraw themselves socially to maximise the time that they want to use for their abnormal eating behaviour. They also avoid situations where food might be served (Reiff \& Reiff, 1992:126).

The above makes it clear that the peer group, as reference group others, could serve as a standard for social comparison for the anorexic adolescent, but this relationship is also a source for social feedback regarding aspects of the physical and material selves.

Interaction with generalised others Generalised others with whom the adolescent is interacting include among others the fashions of the period, the opinions of the mass media, and stereotypes. Kaiser (1990:171-173) points out that because physical appearance is directly discernible it is the most convenient aspect of the self to compare with others and that female adolescents especially are inclined not only to compare themselves with the reference group others, but also the generalised others. 
Fifty percent of adolescents (Nicht, 2000) are regular readers of fashion journals. The "ideal" woman promoted by the media as representative of the generalised others' opinion is far removed from reality. The viewers and readers are misled by the portrayals from the media. Posavac et al (1998:199) contend, "It is likely that the extreme thinness of the models combined with professional photographic techniques and retouching interact to produce a 'superimage' with which most women simply cannot compete". Such misrepresentations put enormous pressures on adolescents and if they feel that they cannot comply with the standard it could lead to a negative perception of the physical as well as the whole self, and according to Kowalski (2000) also to eating disorders. Posovac et al (1998) hold that exposure to the media will only lead to a heightened consciousness of weight if the individual is already dissatisfied with her body. Burns (1981:153) points out that it all has to do with stereotyping and specifically, among female adolescents, that body type is associated with popularity. Very attractive models are often associated with the "what is good" stereotype and beautiful people are often regarded as those that have better opportunities and will perform well when it comes to professions and having life partners (Landreth \& Bower, 2001). Stereotyping can become dangerous when the adolescent does not quite fit into the category, but she is still part or wants to be part of the group. With regard to anorexia nervosa, Stice et al (2002) found that pressure from the media promotes body dissatisfaction and has a negative effect on the adolescent girl's experience of her physical self

Significant others have a special role in providing social feedback to the anorexic adolescent, and it would appear from the aforementioned literature that the generalised others serve as a standard with which the female anorexic adolescent compares her physical self. Because the anorexic adolescent is now in a social-cognitive development phase where the emphasis has moved from significant others to generalised and reference group others, and also in a cognitive development phase where introspection and egocentrism are important (Gormly \& Brodzinsky, 1989:307-314), cognitive processes such as selfattribution probably have a role in her perception and understanding of her self and her behaviour, whether physical appearance or eating behaviour.

\section{CONCLUSION AND IMPLICATIONS FOR FUTURE RESEARCH}

A social-cognitive model holds the view that the female anorexic adolescent:

is an active, dynamic person, taking the responsibility for her own behaviour,

- has a self consisting of various aspects that develops in interaction with herself and

- others and directs her behaviour,

- is capable of evaluating herself and her behaviour and developing a specific perception about that, and

- makes use of cognitive structures and strategies to understand her self and her behaviour,
- the situation in which she is, as well as other people and their behaviour

- so that she is better able to direct her own behaviour.

Such an approach provides the opportunity for the researcher to study the female anorexic adolescent in her entirety, aiming to understand her behaviour, instead of merely trying to identify a few factors or possible causes for her behaviour. This should also give the researcher the opportunity to give a full description of the female anorexic adolescent and her behaviour, and not to resort to reaching a mere cause-and-effect conclusion. Lastly it gives the researcher the opportunity to make use of a qualitative approach to the research, and to use creative, qualitative data gathering and other techniques as part of the research design.

\section{REFERENCES}

BARON, RA \& BYRNE, D. 1987. Social psychology: understanding human interaction. 5th ed. Boston. Allyn and Bacon.

BARLOW, DH \& DURAND, VM. 1999. Abnormal psychology. 2nd ed. Pacific Grove. Brooks/Cole.

BENOKRAITES, NV. 1999. Marriages and families. 3rd ed. Englewood Cliffs. Prentice-Hall.

BLADES, M. 2001. Factors effecting what we eat. Nutrition and Food Science 31(2):71-74.

BLAINE, B \& MCELROY, J. 2002. Selling stereotypes: weight loss informercials, sexism and weightism. Sex Roles: A Journal of Research May 2002:351-358. BLOWERS, LC, LOXTON, NJ, GRADY-FLESSER, M, OCCHIPINTI, S, \& DAWE, S. 2003. The relationship between sociocultural pressure to be thin and body dissatisfaction in preadolescent girls. Eating Disorders 4(3):229-244.

BURNS, RB. 1981. The self concept. 2nd ed. New York. Longman.

BYELY, L, ARCHIBALD, AB, GRABER, J \& BROOKSGUNN, J. 2000. A prospective of familial and social influences on girls' body image an dieting. International Journal of Eating Disorders 28:155-164.

CHARON, JM. 1998. Symbolic interaction. 6th ed. New Jersey. Prentice-Hall.

DALZELL, HJ. 2000. Whispers: The role of family secrets in eating disorders. Eating Disorders 8:43-61. DE KLERK, HM. 1995. ' $n$ Sosiaal-sielkundige benadering tot die studie van menslike gedrag binne die huishoudkunde-studieveld. Journal of Dietetics and Home Economics 23(1):41-47.

DORLAND'S POCKET MEDICAL DICTIONARY.

1982. 23rd ed. London. Saunders.

DREWNOWSKI, A, KURTH, CL \& KRAHN, DD. 1995.

Effects of body image on dieting, exercise, and anabolic steroid use in adolescent males. International Journal of Eating Disorders 17(4):381-386.

ELDREDGE, K, WILSON, GT \& WHALEY, A. 1990. Failure, self-evaluation, and feeling fat in women. International Journal of Eating Disorders 9 (1):37-50. FABIAN, LJ \& Thompson, JK. 1989. Body image and eating disturbances in young females. International Journal of Eating Disorders 8 (1): 63-74. 
FIELD, CA, CAMARGO, CA, TAYLOR, CB, BERKEY, CS, ROBERT, SB \& COLDITZ, GA. 2001. Peer, parent, and media influences on the development of weight concerns and frequent dieting among preadolescents and adolescent girls and boys. Pediatrics 107:54.

FIELDHOUSE, P. 1995. Food and nutrition: costoms and culture. 2nd ed. London. Chapman \& Hall.

FURNHAM, A, BADMIN, N \& SNEADE, 1. 2002.

Body image dissatisfaction: differences in eating, attitudes, self-esteem, and reasons for exercise. The Journal of Psychology 136(6):581-597.

GOFFMAN, E. 1963. Stigma. Englewood Cliffs. Prentice-Hall.

GORMLY, VG \& BRODZINSKY, DM. 1989. Lifespan human development. 4th ed. Chicago. Holt Rinehart Winston.

HART, K \& KENNY, ME. 1997. Adherence to the super woman idea and eating disorder symptoms among college woman. A Journal of Research 36 (7-8):461479.

HEALTH 24: woman common conditions. Accessed 2003. Available on line. http://www.hlth24.co.zaWoman/Commonconditions/711-712

HEILMAN, EE. 1998. The struggle for self. Youth and Society 30(2):182-205.

HILL, AJ \& BHATTI, R. 1995. Body shape perception and dieting in preadolescent British Asian girls: links with eating disorders. International Journal of Eating Disorders 17(2):175-183.

JUNG, J, LENNON, SJ \& RUDD, NA. 2001. Selfschema or self-discrepancy? Which best explains body image? Clothing and Textiles Research Journal 19:171-184.

KAISER, SB. 1990. The social psychology of clothing: Symbolic appearances in context. 2nd ed. New York. Macmillan.

KOWALSKI, KM. 2000. Focuses on the impact of eating habits on teenagers' overall health. INSET: Recognizing Eating Disorders. Current Health 27(4):6-12. KRUCKENBERG, HS. 1987. Judgement of body size and attractiveness by Mexican-American mothers and daughters. A dissertation presented to the Faculty of the Department of Psychology. University of Houston. In Partial Fulfilment of the Degree Doctor of Philosophy.

LANDRETH, S \& BOWER, A. 2001. Is beauty best? Highly versus normally attractive models in advertising. Journal of Advertising 30:1-20.

LIEBERMAN, M, GAUVIN, L, BUKOWSKI, M. \&

WHITE, DR. 2001. Interpersonal influence and disordered eating behaviours in adolescent girls. The role of peer modelling, social reinforcement, and bodyrelated teasing. Eating Behaviours 2(3):215-236. MARCOTTE, D, FORTIN, L, POTVIN, P \& PAPILLON, $M$. 2002. Gender differences in depressive symptoms during adolescents: role of gender-typed characteristics, self-esteem, body image, stressful life evens, and pubertal status. Journal of Emotional and Behavioural Disorders 10(1):29-54.

McINTOSH, J. 1999. Eating disorders and the role of the dietitian in patient care. Cape Town. Health Ahead.

MOORE, DC. 1993. Body image and eating behavior in adolescents. Journal of the American College of Nutrition 12(5):505-510.

MUIR, SL, WERTHEIM, EH \& PAXTON, SJ. 1999. Adolescent girls, first diets: triggers and the role of multiple dimensions of self-concept. Eating Disorders 7:259-270.

NEUMARK-SZTAINER, D \& STOREY, M. 1998. Dieting and binge eating among adolescents: What do they really mean? Journal of the American Dietetic Association 98(4):446-450.

NEUMARK-SZTAINER, D, STOREY, M, PERRY, C \& CASEY, MA. 1999. Factors influencing food choices of adolescents: findings from focus-group discussions with adolescents. Journal of the American Dietetic Association 99 (8):929-934.

NICHT, M. 2000. Listening to girls talk about their bodies. Reclaiming Children and Youth 9(3):182-188. NORRIS, DL. 1986. Anorexia nervosa: the adolescent epidemic. South African Journal of Medical Education 4:39-45.

NUTRITION INTERVENTION IN THE TREATMENT OF ANOREXIA NERVOSA, AND EATING DISORDERS NOT OTHERWISE SPECIFIED, 2001. The American Dietetic Association: Position statement (1998). Journal of the American Dietetic Association 101(7): 810-818.

POSOVAC, HD, POSOVAC, SS \& POSOVAC, EJ. 1998. Exposure to media images of female attractiveness and concern with body weight among young women. Sex roles: A Journal of Research 38(34):187.

PRETORIUS, JVM. 1988. Opvoeding, samelewing, jeug: 'n soio-pedagogiek-leerboek. 2 de uitgawe. Pretoria. JL van Schaik.

PUHL, R. \& BROWNELL, KD. 2003. Ways of coping with obesity stigma: review and conceptual analysis. Eating Behaviours 4(1):53-78.

REIFF, DW \& REIFF, KKL. 1992. Eating disorders. Nutrition therapy in the recovery process. Maryland. Aspen.

SLABBER, M.1985. Anorexia nervosa. Journal of Dietetics and Home Economics 13(2): 55-59.

STICE, E, MAXFIELD, J \& WELLS, T. 2002. Adverse effects of social pressure to be thin on young women: An experimental investigation of the effects of "fat talk". Wiley InterScience www.interscience.wiley.com DOI: 10.1002/eat.10171.

TAYLOR, CB, SHARPE, T, SHISSLAK, C, BRYSON, S, ESTES, LS., GRAY, N, McKNIGHT, K M, CRAGO, M, KRAEMER, H \& KILLEN, JD. 1998. Factors with weight concerns in adolescent girls. International Journal of Eating Disorders 24: 31-42.

THOM, DP, LOUW, AE, VAN EDE, DM \& FIRNS, I. Adolescence. In LOUW, DA, VAN EDE, DM \& LOUW, AE. 1998. Human development. 3rd ed. Pretoria. Kagiso.

THOMPSON, AM \& CHAD, KE. 2000. The relationship of pubertal status to body image, social physique anxiety, preoccupation with weight and nutritional status in young females. Canadian Journal of Public Health 91(3):207-211.

TIGGEMANN, M. 1992. Body size dissatisfaction: an individual differences in age and gender, and relationship with self-esteem. Personality and individual Dif- 
ferences 13(1):39-43.

TIGGEMANN, M \& DYER, G.M. 1995. Ideal body shape preferences and eating disorders scores in adolescent women. Psychology and Health 10:345347.

TOUYZ, SW, BEUMONT, PJV, COLLINS, JK, Mc CABE, M \& JUPP, J. 1984. Body shape perception and its disturbance in anorexia nervosa. British Journal of Psychiatrics 144:167-171.

VANDER WAL, JS \& THELEN, MH. 2000. Predictors of body image dissatisfaction in elementary-age school girls. Eating behaviours 1(2):105-122.

WARDLAW, GM. 1999. Perspectives in nutrition. 4th ed. Boston. McGraw-Hill.

WAUGH, E \& BULIK, CM. 1999. Offspring of women with eating disorders. International Journal of Eating Disorders 25:123-133.

WHITNEY, EN \& ROLFES, SR. 1999. Understanding nutrition. 8th ed. London. Wadsworh.

WHITNEY, EN, CATALDO, CB, DEBRUYNE, LK \& ROLFES, SR. 2001. Nutrition for Health and Health care. 6th ed. Londen. Wadsworth. 